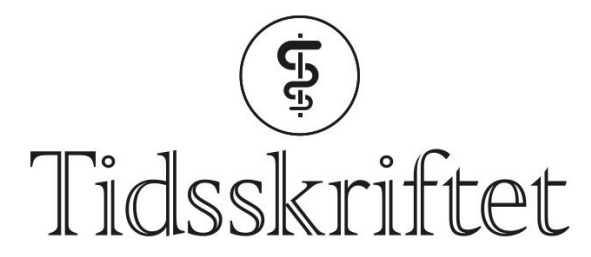

DEN NORSKE LEGEFORENING

\title{
Et visuelt, fargerikt og småkirurgisk fag
}

MITT FAGFELT

Trine Lilly Halvorsen er avtalespesialist i hud- og veneriske sykdommer og daglig leder ved Kolbotn Hudlegesenter.

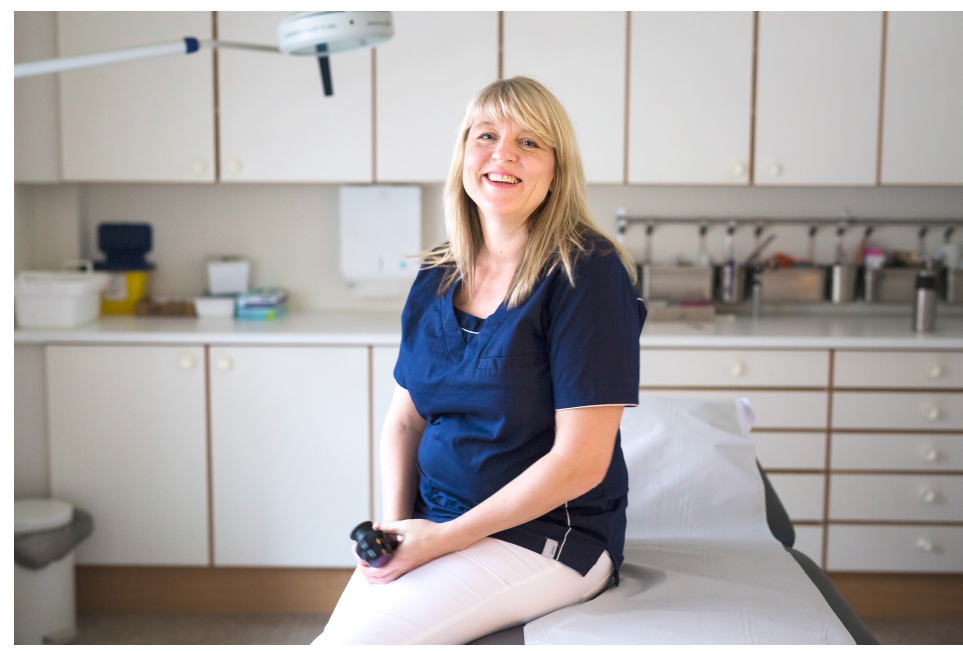

Foto: Kristine Lindebø

- Mitt valg av spesialitet var tilfeldig. Jeg ønsket å spesialisere meg innen et fagfelt hvor jeg også kunne jobbe utenfor sykehus. Jeg hadde flaks og ble tilbudt et vikariat ved hudavdelingen ved Ullevål sykehus. Litt usikker var jeg før jeg begynte, men jeg har aldri angret, forteller Trine Lilly Halvorsen.

Hun sier hun liker hudfaget veldig godt fordi det er allsidig, med innslag av både indremedisinske og kirurgiske problemstillinger.

- Faget er også i stadig utvikling. Den kirurgiske delen har vokst de siste tiårene på grunn av $\emptyset$ kende forekomst av hudkreft og føflekkreft. Og biologisk terapi har revolusjonert behandlingen av mange kronikere. Livet som hudlege er hektisk, men godt, og jeg gleder meg hver dag til hvert pasientmøte. Jeg liker at hudpasienter kommer i alle aldre og kjønn og at de er stort sett veldig fornøyde, sier hun, og legger til:

- Dessverre er det mangel på hudleger, og utdanningskapasiteten i Norge er begrenset. Denne mangelen har vi kjent til og visst ville komme i lang tid. Det har vært lite politisk vilje til å øke antall utdanningsstillinger og antall spesialisthjemler. Så at det er lang ventetid på hudlegetime i det offentlige, bør ikke forbause noen.

\section{Kan du fortelle noe viktig som skjer i faget ditt for tiden?}

- De siste årene har det kommet mange artikler og mye ny kunnskap rundt dermatoskopi 
eller dermoskopi. Dermoskopi er internasjonalt foreslått som nytt navn på undersøkelsesmetoden. Et dermatoskop er et slags forstørrelsesglass hudleger bruker til å undersøke pigmenterte lesjoner som føflekker og maligne melanomer. Gjennom dermatoskopet ser man morfologien eller det submakroskopiske bildet man ikke kan se med det blotte øyet. Vi ser farger og strukturer - og ut fra dette tolker vi resultatet.

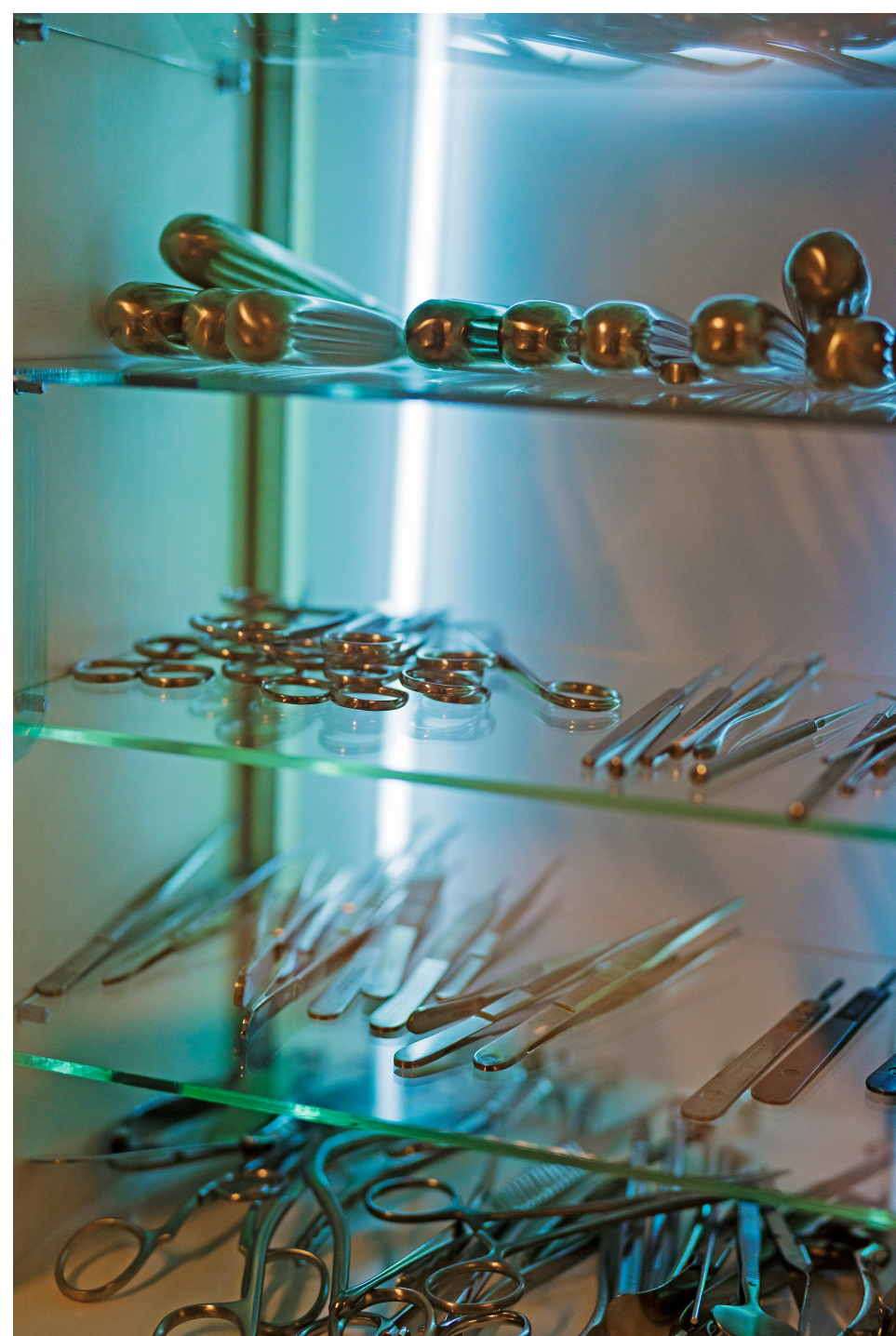

I de senere år har det kommet mange publikasjoner om spesifikke mønstre i forskjellige pigmenterte lesjoner, slik at for eksempel et malignt melanom kan oppdages på et tidlig stadium. Det er økende kunnskap om helt spesifikke mønstre i ikke-pigmenterte og inflammatoriske hudforandringer. For eksempel kan psoriasis ha et tydelig uttrykk i dermatoskopet. Jeg anbefaler å søke opp Dermoscopedia.org for ytterligere informasjon.

\section{Kan du anbefale en ny interessant artikkel?}

- Det må være A consensus-based practical and daily guide for the treatment of acne patients (1). Jeg er opptatt av at pasienter med akne skal få god informasjon, behandling, veiledning og oppfølging i allmennpraksis. Akne rammer over $80 \%$ av ungdom og er ofte kronisk. De fleste aknepasienter kan følges opp i allmennpraksis. I denne artikkelen får man veiledning i hvilken type behandling man bør velge, avhengig av type akne og hva som kan være årsaken dersom den forventede effekten uteblir, sier hun. 


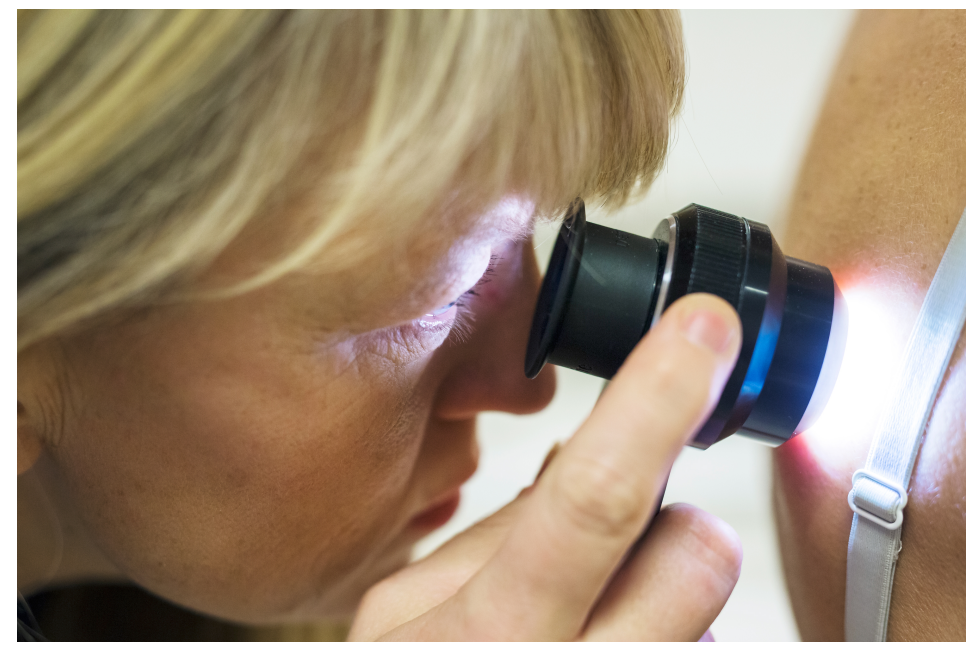

- For å oppnå et godt behandlingsresultat er det viktig med god informasjon om hudpleie, valg av hudprodukter, medisinsk behandling og bivirkninger. Pasienten må også fortsette med vedlikeholdsbehandling etter at han eller hun er blitt bra. Sammen med to kolleger lager jeg for tiden en akneguide for allmennleger. Den vil være tilgjengelig i 2018.

\section{Hva er ditt favoritthjelpemiddel på jobb?}

- Dermatoskopet mitt. Det bruker jeg hver eneste dag - mange ganger om dagen. Gjennom et dermatoskop kan mønster og farger i huden fortelle hva vi ser og hvor i huden forandringene sitter. For eksempel er pigmentet i føflekker helt øverst i huden svart, lenger ned i huden brunt, så grått og helt dypest i huden blått, forteller hun.

- Dermatoskop fås nå med polarisert lys. Med polarisert lys er det ikke nødvendig å bruke olje ved dermoskopi. Oljen gjorde det øverste hudlaget mer transparent ved undersøkelse. Et dermatoskop med polarisert lys er litt dyrere, men er klart å anbefale om man ønsker å investere i et slikt. Det gjør hverdagen lettere. Kanskje kan allmennleger i fremtiden kurses i dermoskopi. Det ville gi dem $\emptyset$ kt trygghet i vurdering av føflekker og de vil lettere kunne skille for eksempel en seboreisk keratose fra en føflekk. Det er et problem at vi på den ene side ønsker at alle skal følge med på sine føflekker og få dem sjekket dersom man er usikker - samtidig som systemet har begrenset kapasitet.

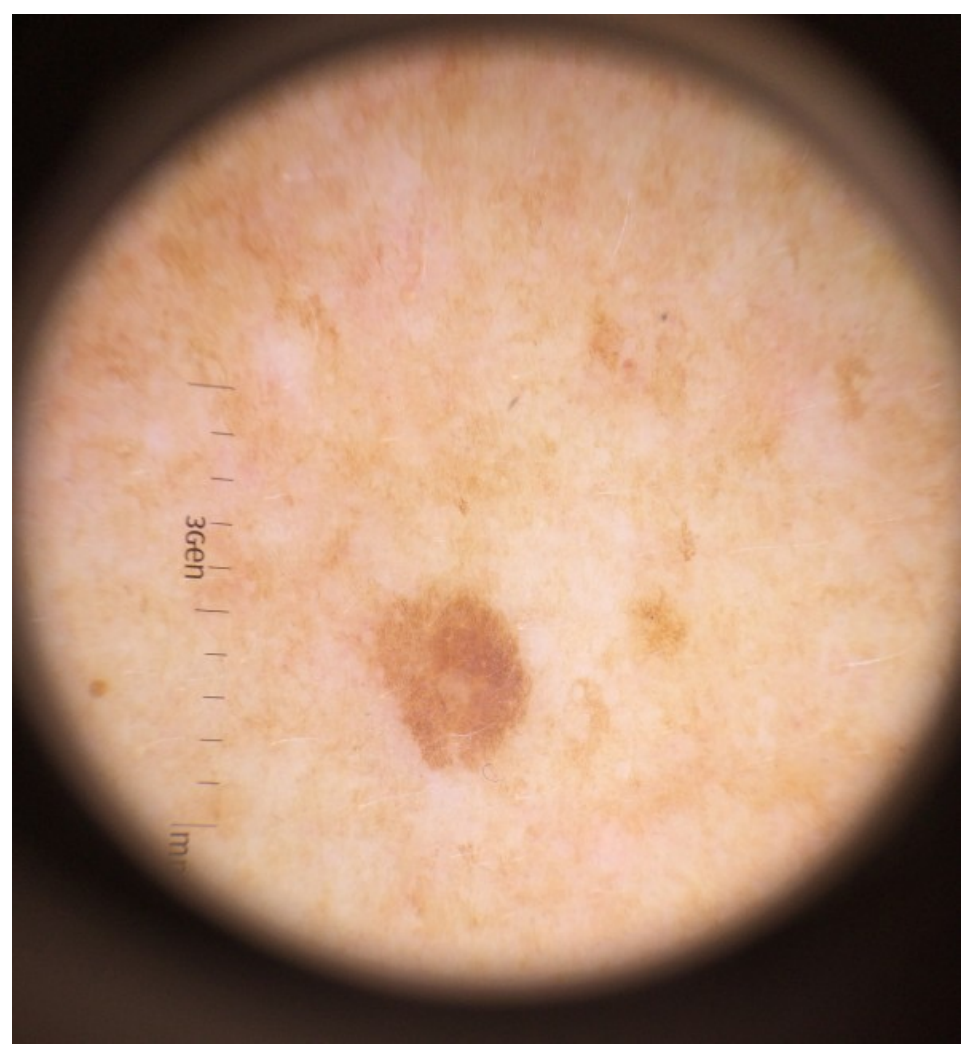


LITTERATUR:

1. Gollnick HP, Bettoli V, Lambert J et al. A consensus-based practical and daily guide for the treatment of acne patients. J Eur Acad Dermatol Venereol 2016; 30: 1480 - 9o. [PubMed][CrossRef]

Publisert: 5. februar 2018. Tidsskr Nor Legeforen. DOI: 10.4045/tidsskr.17.1042

(C) Tidsskrift for Den norske legeforening 2020. Lastet ned fra tidsskriftet.no 